\title{
MAPPING AND CORRELATION ANALYSIS OF EFFICIENCY AND PROFITABILITY: THE CASE OF ISLAMIC RURAL BANK IN INDONESIA
}

\author{
Titi Dewi Warninda \& M. Nadratuzzaman Hosen ${ }^{1}$
}

\begin{abstract}
Mapping and Correlation Analysis of Efficiency and Profitability: The Case of Islamic Rural Bank in Indonesia. This research aims to analyze efficiency and profitability of Islamic Rural Banks in Indonesia using Variable Returns to Scale model of Data Envelopment Analysis and efficiency-profitability matrix. The results of this research show that most of Islamic Rural Banks are included in the Dog quadrant (high efficiency but low profitability) and Sleeper quadrant (low efficiency but high profitability). Meanwhile, the result of correlation analysis between efficiency and profitability indicates that efficiency has a negative correlation with profitability. Negative correlation of efficiency and profitability is in accordance with the result of efficiency-profitability matrix. The results of this research show that not all of Islamic Rural Bank which have high efficiency are also having high profitability.
\end{abstract}

Keywords: Efficiency, Profitability, Data Envelopment Analysis, Islamic Rural Bank

\begin{abstract}
Abstrak. Pemetaan dan Analisis Hubungan Antara Efisiensi dan Profitabilitas: Studi BPRS di Indonesia. Tujuan dari penelitian ini ialah untuk menganalisis efisiensi dan profitabilitas pada BPRS di Indonesia dengan menggunakan model Variable Returns to Scale pada Data Envelopment Analysis (DEA) dan matriks efisiensi-profitabilitas, hasil penelitian menunjukkan bahwa sebagian besar Bank Pembiayaan Rakyat Syariah (BPRS) termasuk dalam kuadran Dog (efisiensi tinggi dan profitabilitas rendah) dan kuadran Sleeper (efisiensi rendah dan profitabilitas tinggi). Sementara itu, hasil analisis korelasi antara efisiensi dan profitabilitas mengindikasikan bahwa efisiensi memiliki hubungan negatif dengan profitabilitas. Hubungan negatif ini sesuai dengan hasil matriks efisiensi-profitabilitas. Hasil penelitian menunjukkan bahwa untuk sebagian besar Bank Pembiayaan Rakyat Syariah (BPRS) di Indonesia, efisiensi tinggi tidak berhubungan positif dengan profitabilitas tinggi.
\end{abstract}

Kata kunci: Efisiensi, Profitabilitas, Data Envelopment Analysis, BPRS

First draft: September, 10th 2014, Revision: November, 25th 2014, Accepted: December, $10^{\text {th }}$ 2014

${ }^{1}$ Syarif Hidayatullah State Islamic University. Jl. Ir. H. Juanda No. 95, Ciputat, South Tangerang, Banten, Indonesia.

Email:warninda@yahoo.com; mnhosen@yahoo.com 


\section{Introduction}

Islamic Rural Bank is a rural bank that operates based on the principles of Islamic law. Islamic Rural Bank is founded to serve Micro and Small Enterprises that need fast, easy, and simple approval process. Because of its role in giving services to Micro and Small Enterprises, Islamic Rural Bank has an important role in improving financial inclusion. Islamic Rural Banks has a rapid growth experience in Indonesia. In 2005, there were only 92 Islamic Rural Banks and 158 in 2012. By 2012, they have 91 branch offices and 152 cash offices. In 2005, total net assets reached 585 billion rupiah, and increased up to 4.7 trillion rupiahs in 2012. They also have disbursed 417 billion rupiah total financing in 2005 and became 3 trillion rupiah in 2012 .

Although according to Islamic Banking Statistic published by Indonesian Central Bank; the amount of asset and financing has increased, however, the profitability of Islamic Rural Banks demonstrated by Return on Assets (ROA) showed a reduction. Profitability of Islamic Rural Banks reached $4.05 \%$ in 2005, and became $2.67 \%$ in 2011 . In 2012, the profitability decreased again to $2.64 \%$. The decrease of Indonesian Islamic Rural Banks profitability becomes the background of this efficiency-profitability mapping research. Based on the study of Noor and Ahmad (2012) about Islamic bank in the world, there is a positive correlation between efficiency and profitability. It means that Decision Making Unit (DMU) which has high level of efficiency will have high profitability. Meanwhile, according to Abu-Alkheil, Burghof, and Khan (2012), not all of Decision Making Units (DMUs) which have high efficiency are also having high profitability. Research on efficiency and profitability of Indonesian Islamic Rural Banks will determine whether there are a lot of inefficient Islamic Rural Banks and whether the inefficient Islamic Rural Banks are also having lower profitability than the more efficient Islamic Rural Banks. So, there will be a map about efficiency-profitability of Indonesian Islamic Rural Banks.

In this research, Return on Assets (ROA) is used to mesure the profitability Data Envelopment Analysis in non parametric approach is used to measure the efficiency. DEA is a linear programming method that is used to measure the efficiency of a Decision Making Unit (DMU). DEA formed a standard of DMU that is efficient compared to other inefficient DMU (Said, 2013). DEA model in this research uses Variable Returns to Scale (VRS) assumption. This assumption is used to determine the technical efficiency without scale efficiency (pure technical efficiency). This study uses intermediation approach to determine the inputs and outputs that are used in the DEA model. Intermediation approach is used because the main function of Islamic Rural Banks is as intermediary between the depositors 
and those who need funds.

Previous research on the efficiency of Islamic Rural Banks is still rare. Most of previous researches are about efficiency of Islamic banks, microfinance, and rural banks. Some previous researches about efficiency of microfinance using DEA are as follow. Kipesha (2013) studied on technical efficiency of Microfinance Institutions (MFIs) in Tanzania, another in 2012 was about efficiency of MFIs in East Africa. The research of Hassan and Sanchez (2009) was about technical efficiency and scale efficiency of the MFIs in Latin American, Middle East and North African, and South Asian countries. Haq, Skully, and Pathan (2010) conducted a study on the efficiency of 39 Microfinance Institutions (MFIs) in Africa, Asia, and Latin America. The research of Babu, Kasilingam, and Kasilingam (2011) was about the efficiency of MFIs in India.

This research aims to analyze profitability and efficiency of Islamic Rural Banks in Indonesia. In using the efficiency-profitability matrix, this research will show whether Islamic Rural Banks that have high efficiency will also have high profitability. The result of this research will enhance the literature about efficiency and profitability of Islamic Rural Banks. This research also analyzes the correlation between efficiency and profitability and the correlation among other variables. The finding of this research will contribute in the development of Islamic Rural Banks and support the sustainability of financial inclusion in Indonesia.

There are some differentiations over previous researches. First, this research uses the data of Islamic Rural Banks in Indonesia. Second, this research gives analysis of efficiency-profitability mapping using efficiency-profitability matrix. Third, this research analyzes the correlations between efficiency and profitability and among other variables to find the consistency with the result of efficiency-profitability matrix.

\section{Literature Review}

Most of previous researches are about efficiency of conventional microfinance institutions (MFIs) and rural banks. Previous research on the efficiency of Islamic Rural Bank is still rare. Some previous researches about efficiency of microfinance using DEA are as follows.

Kipesha (2013) has done research about technical efficiency of Microfinance Institutions in Tanzania for the period of 2009-2011. The result of the research indicated a high level of production efficiency and low level of intermediation efficiency. The research of Kipesha (2013) has recommended that MFIs in Tanzania should reduce their operation costs, increase revenues, and increase resource allocation to get higher intermediation efficiency. The research of Mohindra and 
Kaur (2011) was about regional rural banks efficiency in India after reformation period. The result of the research using DEA showed a decrease of rural banks technical efficiency after deregulation policy. The research of Khankoje and Sathye aimed (2008) analyzed the impact of regional rural banks restructuring in India on production efficiency, using DEA. The result of the research indicated that restructuring program on Indian rural banks showed a positive impact.

The study of Hassan dan Sanchez (2009) analysed about technical and scale efficiency of MFI in Latin America countries, Middle East and North Africa (MENA) countries, and South Asia countries. The result of the study showed that formal MFIs (banks and credit unions) have higher technical efficiency level than non formal MFIs (non profit organization and non financial institutions). MFIs in South Asian have higher technical efficiency than Latin American and MENA MFIs.

Haq, et.al. (2010) had a research about efficiency of MFI in Africa, Asia, and Latin America using DEA. The research showed that non government MFIs had highest level of production efficiency. Meanwhile, MFIs that are banks have highest intermediation efficiency. Babu, Kasilingam, and Kasilingam (2011) studied about efficiency of MFI in India. The study found that the average efficiency score was very low and more than 65 percent of the MFIs have below mean efficiency level. The cost per borrower variable has significant influence in measuring efficiency of MFIs. The study also revealed that non-profit microfinance institutions have shown a high efficiency compared to profit organization. Jayamaha and Mula (2010) studied about efficiency of Cooperative Rural Banks in India using DEA and analyze the correlations between efficiency and financial factors. The result of the study indicated that asset quality, loan portfolio yield, operational efficiency, and operational self sufficiency variables have significant correlations with technical efficiency.

\section{Methods}

The scope of the study is Islamic Rural Banks in Indonesia. It is because the DEA software for calculating efficiency only can be used in the positive input and output variables. The research only uses Islamic Rural Banks that have a positive net income. The data is taken from 2012 financial reports of Indonesian Islamic Rural Banks.

The proxy of profitability is Return on Assets (ROA). This research uses Data Envelopment Analysis (DEA) for efficiency measurement. DEA is a linear programming method that is used to measure the efficiency of a Decision Making Unit (DMU). DEA form is a standard that a DMU is efficient compared to other inefficient DMU (Said, 2013). 
This research will analyze the pure technical efficiency of Islamic Rural Banks. Technical efficiency is the ability of a DMU to produce as many outputs as possible by using a particular input, or produce a certain amount of outputs using a minimum amount of inputs. This study uses the DEA output-orientation. This is because Islamic Rural Banks operate in a competitive environment and should strive for providing the best products and services to customers. Islamic Rural Banks are more likely to have a competitive advantage by increasing the output produced rather than reducing the inputs used.

The measurement of pure technical efficiency uses Variable Returns to Scale (VRS) model. VRS models or BCC (Banker, Charnes, and Cooper) model were made by Banker, Charnes, and Cooper in 1984 and were an improvement of CRS model by adding variable returns to scale assumptions. VRS model provides a measurement of pure technical efficiency, which is technical efficiency without scale efficiency. DEA-model in this research consists of two inputs and two outputs. This research uses cost of wages and salaries, and total customer deposits (total deposits) as inputs, while the outputs using total financing and net income, as used by Onour and Abdalla (2011).

Islamic Rural Banks efficiency-profitability mapping uses efficiencyprofitability matrix that has a structure such as the product portfolio matrix (AbuAlkheil, et.al, 2012). Efficiency-profitability matrix consists of four quadrants as follows: First, Star quadrant: consists of a DMU that has a high level of profitability and efficiency. This is the best DMU. Second, Sleeper quadrant: consists of a DMU that has higher profitability but lower efficiency. This is not a good sign from long-term perspective. The high profitability is due to primarily more favorable environmental conditions than good management. Third, Question Mark quadrant: consist of a DMU that has a low level of profitability and efficiency. This DMU has the potential to achieve higher level of profitability and efficiency. Fourth, Dog quadrant: consists of a DMU which has a low level of profitability but high efficiency. The DMU is efficient but still make less profit. The DMU operates efficiently but has low profitability due to unfavorable environment.

Table 1: Efficiency-Profitability Matrix

\begin{tabular}{lll}
\hline Profitability & & \\
\hline High & Sleeper & Star \\
Low & Question Mark & Dog \\
Efefficiency & Low & High \\
\hline
\end{tabular}


Star quadrant consists of Islamic Rural Banks that have high efficiency and profitability. Dog quadrant consists of Islamic Rural Banks that have high level of efficiency but low profitability. Sleeper quadrant consists of Islamic Rural Banks that have low level of efficiency but high profitability. While Question Mark quadrant consists of Islamic Rural Banks that have low efficiency and profitability.

The criteria for high or low level of profitability and efficiency are based on the median value of the overall profitability and efficiency data. Islamic Rural Bank which has a higher profitability or efficiency than the median value or equal with the median value is Islamic Rural Banks with high level of profitability or efficiency. While Islamic Rural Bank which has a lower profitability or efficiency than the median value is Islamic Rural Bank with low level of profitability or efficiency.

Correlations test aims to find the correlations between efficiency and profitability, and among other variables. Other variables in the correlations test are equity capital to total assets (CAP), natural logarithm of total assets (SZE), financing to deposits ratio (FDR), and operating expense to total assets $(\mathrm{OXN})$.

\section{Discussion}

After calculating the profitability (ROA) and the efficiency based on pure technical efficiency, the profitability and efficiency are grouped into the high and low groups of efficiency and profitability. Efficiency-profitability mapping in the efficiency-profitability matrix based on the high and low groups of efficiency and profitability will show which Islamic Rural Bank that is included in the Star quadrant, Dog quadrant, Sleeper quadrant, or Question Mark quadrant.

Some of Islamic Rural Banks are included in the Star quadrant of efficiencyprofitability matrix, means that they have high profitability and high efficiency. Islamic Rural Banks that are included in the Star quadrant are as follows.

Table 2. Islamic Rural Banks in the Star Quadrant

\begin{tabular}{clcc}
\hline No & Islamic Rural Banks & Efficiency & Profitability (\%) \\
\hline 1 & Bangka & 1 & 4.350 \\
2 & Dana Hidayatullah & 1 & 7.700 \\
3 & Situbondo & 1 & 5.990 \\
4 & Surya Sejati & 1 & 3.780 \\
5 & Harta Insan Karimah & 0.977 & 4.400 \\
6 & Baitul Muawanah & 0.937 & 5.100 \\
7 & Dinar Ashri & 0.926 & 6.000
\end{tabular}


Titi Dewi Warninda: Mapping and Correlation Analysis

\begin{tabular}{clcc}
8 & Amanah Rabbaniah & 0.862 & 3.240 \\
9 & Jabal Tsur & 0.848 & 42.070 \\
10 & Barkah Gemadana & 0.834 & 5.070 \\
11 & Metro Madani & 0.825 & 4.820 \\
12 & Artha Mas Abadi & 0.779 & 5.280 \\
13 & Bumi Rinjani Kepanjen & 0.771 & 7.200 \\
14 & Artha Pamenang & 0.746 & 7.250 \\
15 & Khasanah Ummat & 0.739 & 14.580 \\
16 & Bangun Drajat Warga & 0.734 & 4.210 \\
\hline
\end{tabular}

Some of Islamic Rural Banks are included in the Dog quadrant of efficiencyprofitability matrix. It means that they have high efficiency but low profitability. Islamic Rural Banks that are included in the Dog quadrant are as follows:

Table 3. Islamic Rural Banks in the Dog Quadrant

\begin{tabular}{clcc}
\hline No & Islamic Rural Banks & Efficiency & Profitability (\%) \\
\hline 1 & Al Hijrah Amanah & 1 & 0.610 \\
2 & Al Ihsan & 1 & 2.310 \\
3 & Al Salaam Amal Salman & 1 & 2.360 \\
4 & Amanah Ummah & 1 & 2.690 \\
5 & Dana Mulia & 1 & 1.450 \\
6 & Gunung Slamet & 1 & 2.290 \\
7 & Bumi Rinjani Probolinggo & 1 & 0.410 \\
8 & Hareukat & 1 & 1.440 \\
9 & Indo Timur & 1 & 1.820 \\
10 & Barakah Nawaitul Ikhlas & 1 & 0.700 \\
11 & Carana Kiat Andalas & 1 & 0.180 \\
12 & Barokah Dana Sejahtera & 0.964 & 1.670 \\
13 & Amanah Sejahtera & 0.947 & 2.880 \\
14 & Insan Madani & 0.946 & 1.380 \\
15 & Buana Mitra Perwira & 0.943 & 2.910 \\
16 & FORMES & 0.912 & 1.020 \\
17 & Margirizki Bahagia & 0.903 & 2.850 \\
18 & Bhakti Haji & 0.902 & 2.800 \\
19 & Hikmah Wakilah & 0.885 & 2.600
\end{tabular}




\begin{tabular}{llcl}
20 & Danagung Syariah & 0.856 & 1.710 \\
& PT BPRS Gajah Tongga Kota & & \\
21 & Piliang & 0.847 & 2.260 \\
23 & Berkah Ramadhan & 0.84 & 1.890 \\
24 & Bl Ma'soem Syari'ah & 0.821 & 2.760 \\
25 & Lantabur & 0.816 & 2.490 \\
26 & Ikhsanul Amal & 0.805 & 2.910 \\
27 & Tanggamus & 0.801 & 1.930 \\
28 & Muamalat Harkat & 0.784 & 2.150 \\
29 & Amanah Insani & 0.776 & 2.730 \\
30 & Arta Leksana & 0.752 & 2.400 \\
31 & Karya Mugi Sentosa & 0.748 & 2.390 \\
\hline
\end{tabular}

Some of Islamic Rural Banks are included in the Sleeper quadrant of efficiencyprofitability matrix. It means that they have low efficiency but high profitability. Islamic Rural Banks that are included in the Sleeper quadrant are as follows:

Table 4. Islamic Rural Banks in the Sleeper Quadrant

\begin{tabular}{clcc}
\hline No & Islamic Rural Banks & Efficiency & Profitability (\%) \\
\hline 1 & Artha Surya Barokah & 0.701 & 9.400 \\
2 & Sukowati Sragen & 0.653 & 4.780 \\
3 & Mentari & 0.632 & 7.230 \\
4 & Al-Yaqin & 0.631 & 4.330 \\
5 & Baktimakmur Indah & 0.626 & 3.980 \\
6 & Harta Insan Karimah Parahyangan & 0.624 & 3.400 \\
7 & Cilegon Mandiri & 0.622 & 6.740 \\
8 & Al Hidayah & 0.614 & 3.210 \\
9 & Mitra Cahaya Indonesia & 0.613 & 3.280 \\
10 & Cempaka Al Amin & 0.612 & 5.430 \\
11 & Safir & 0.602 & 4.280 \\
12 & Bumi Rinjani & 0.599 & 4.090 \\
13 & Madinah & 0.598 & 6.600 \\
14 & Tanmiya Artha & 0.597 & 4.960 \\
15 & Al Mabrur & 0.596 & 3.480
\end{tabular}


Titi Dewi Warninda: Mapping and Correlation Analysis

\begin{tabular}{llcc}
16 & Daya Artha Mentari & 0.589 & 3.920 \\
17 & Artha Madani & 0.588 & 4.660 \\
18 & Artha Amanah Ummat & 0.571 & 3.540 \\
19 & Jabal Nur & 0.561 & 4.640 \\
20 & Patuh Beramal & 0.56 & 7.280 \\
21 & Rajasa & 0.551 & 23.390 \\
22 & Bumi Rinjani Batu & 0.512 & 34.880 \\
23 & Mulia Berkah Abadi & 0.501 & 16.390 \\
24 & Way Kanan & 0.492 & 11.850 \\
25 & Baiturridha Pusaka & 0.479 & 5.610 \\
26 & Al Mabrur Babadan & 0.476 & 4.890 \\
27 & Kotabumi & 0.446 & 3.720 \\
28 & Artha Fisabilillah & 0.414 & 5.700 \\
29 & Bhakti Sumekar & 0.362 & 6.220 \\
30 & Harta Insan Karimah Cibitung & 0.35 & 7.210 \\
31 & Investama Mega Bakti & 0.317 & 3.480 \\
\hline
\end{tabular}

Some of Islamic Rural Banks are included in the Question Mark quadrant of efficiency-profitability matrix. It means that they have low efficiency and profitability. Islamic Rural Banks that are included in the Question Mark quadrant are as follows:

Table 5. Islamic Rural Banks in the Question Mark Quadrant

\begin{tabular}{clcc}
\hline No & Islamic Rural Banks & Efficiency & Profitability (\%) \\
\hline 1 & Bumi Rinjani Malang & 0.700 & 1.390 \\
2 & Mitra Amal Mulia & 0.693 & 1.860 \\
3 & Bina Amanah Satria & 0.665 & 3.120 \\
4 & Asad Alif & 0.660 & 2.300 \\
5 & Suriyah & 0.657 & 2.810 \\
6 & PNM Binama & 0.640 & 1.760 \\
7 & Adeco & 0.623 & 1.360 \\
8 & Ampek Angkek Candung & 0.621 & 2.500 \\
9 & Puduarta Insani & 0.590 & 1.920 \\
10 & Harta Insan Karimah Bekasi & 0.561 & 2.600 \\
11 & Mandiri Mitra & 0.557 & 0.400
\end{tabular}




\begin{tabular}{llll}
12 & Bina Rahmah & 0.529 & 2.530 \\
13 & Bandar Lampung & 0.526 & 2.490 \\
14 & Haji Miskin & 0.460 & 0.220 \\
15 & Artha Sinar Mentari & 0.338 & 3.130 \\
\hline
\end{tabular}

According to tables above, there are 16 Islamic Rural Banks included in the Star quadrant and 31 Islamic Rural Banks in the Dog quadrant. There are 31 Islamic Rural Banks included in the Sleeper quadrant and 15 Islamic Rural Banks in the Question Mark quadrant. Efficiency-profitability matrix is as follows:

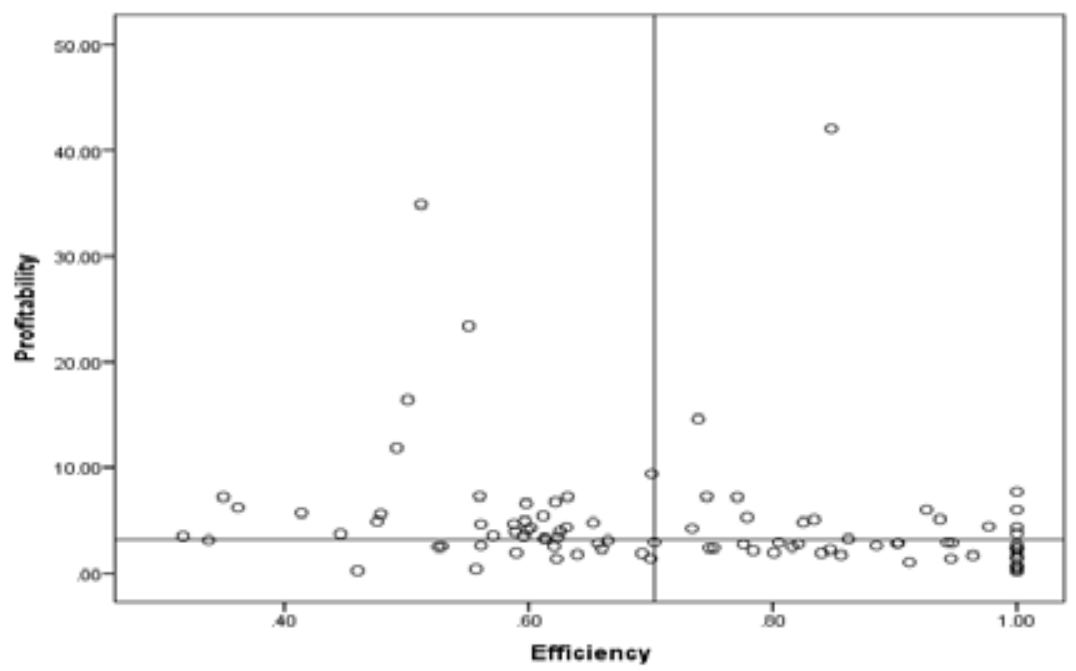

Figure 1: Efficiency-Profitability Matrix

Four quadrants in efficiency-profitability matrix above show the most of Islamic Rural Banks that included in the Dog quadrant and Sleeper quadrant. The quadrants consist of Islamic Rural Banks which have high efficiency but low profitability and Islamic Rural Banks which have low efficiency but high profitability, respectively. The result shows that most of Islamic Rural Banks that have high efficiency do not have high profitability, vice versa.

Based on the result of efficiency-profitability matrix above, it is needed to analyze the correlations between efficiency and profitability and among other variables, especially to analyze the consistency with the result of efficiencyprofitability matrix. 
Titi Dewi Warninda: Mapping and Correlation Analysis

Table 6. Correlation Test Result

\begin{tabular}{ccccccc}
\hline & CAP & EFF & FDR & OXN & ROA & SZE \\
\hline CAP & 1.000000 & & & & & \\
EFF & 0.184463 & 1.000000 & & & & \\
FDR & -0.007775 & 0.000796 & 1.000000 & & & \\
OXN & 0.059928 & 0.000636 & 0.931688 & 1.000000 & & \\
ROA & -0.444132 & -0.478985 & -0.053812 & -0.051274 & 1.000000 & \\
SZE & 0.029996 & 0.098393 & -0.045359 & -0.060634 & 0.032244 & 1.000000 \\
\hline
\end{tabular}

Table 6 shows that efficiency has negative correlation with profitability. It also shows the variable that has a positive correlation with profitability. However, we still need further reaseach related to other variables that have negative correlations with profitability such as equity capital, financing, and operating expenses.

\section{Conclusion}

Based on the findings and analysis of the efficiency-profitability mapping of Islamic Rural Banks in Indonesia, not all of Islamic Rural Banks that have high efficiency are also have high profitability. Most of Islamic Rural Banks are included in the Dog and Sleeper quadrants It means that those Islamic Rural Banks have high efficiency but low profitability and have low efficiency but high profitability, respectively.

The result of correlations analysis shows that Islamic Rural Banks efficiency has negative correlation with profitability. This result is in accordance with the result of efficiency-profitability mapping that most of Islamic Rural Banks have high efficiency but low profitability (in the Dog quadrant) and have low efficiency but high profitability (in the Sleeper quadrant). The result of this research is in accordance with the research of Abu-Alkheil, Burghof, and Khan (2012) that not all of Decision Making Units (DMUs) which have high efficiency are also having high profitability.

Islamic Rural Banks that are in the Dog quadrant should have more favorable environment to increase their profitability. Meanwhile, Islamic Rural Banks that are in the Sleeper quadrant should improve their management because they have high profitability but low efficiency. Some Islamic Rural Banks are included in the Question Mark quadrant, means that they have the potential to achieve higher level of profitability and efficiency if they get more favorable environment and additional appropriate resources. 


\section{References}

Abu-Alkheil, A. M., et.al. 2012. Islamic Commercial Banking in Europe: a CrossCountry and Inter-Bank Analysis of Efficiency Performance. International Business and Economics Research Journal, 11 (6), 2012, pp. 647-676.

Babu, C., et.al. 2011. Technical Efficiency of MFI's and Its Determinants: An Empirical Study. Tecnia Journal of Management Studies, 6 (2), pp 40-49.

Hassan, M. K. \& B. Sanchez. 2009. Efficiency Analysis of Microfinance Institutions in Developing Countries. Working Paper, Network Financial Institute, Indiana State University.

Haq, M., et.al. 2010. Efficiency of Microfinance Institutions: A DEA Analysis. AsiaPacific Financial Markets, 17, pp. 63-97.

Jayamaha, A. \& J.M. Mula. 2010. Financial Practices and Efficiency of Cooperative Rural Banks in Sri Lanka. 1st International Conference on Business and Information: Researching Realities of Management Phenomenon (ICBI 2010), Colombo, Sri Lanka.

Khankhoje, D. \& M. Sathye. 2008. Efficiency of Rural Banks: The Case of India. International Business Research, 1 (2), pp. 140-149.

Kipesha, E. F. 2012. Efficiency of Microfinance Institutions in East Africa: A Data Envelopment Analysis. European Journal of Business and Management, 4 (17), pp. $77-88$.

Kipesha, E. F. 2013. Production and Intermediation Efficiency of Microfinance Institutions in Tanzania. Journal of Finance and Accounting, 4 (1), 149159.

Mohindra, V. \& G. Kaur. 2011. Efficiency of Regional Rural Banks in India: An Application of Data Envelopment Analysis. Economic Affairs, 56 (2), 187196.

Noor, M. A. \& N.H. Ahmad. 2012. The Determinants of World Islamic Banks' Efficiency: Does Country Income Level Have an Impact? Journal of Islamic Economics, Banking and Finance, 8 (2), pp. 9 - 44.

Onour, I. A. \& A.M.A. Abdalla. 2011. Efficiency of Islamic Banks in Sudan: A NonParametric Approach. Journal of Islamic Economics, Banking and Finance, 7 (4), pp. 79-92.

Said, A. 2013. Risk and Efficiency in the Islamic Banking System: The Case of Selected Islamic Banks in MENA Region. International Journal of Economics and Financial Issues, 3 (1), pp. 66-73. 